Relations industrielles

Industrial Relations

\title{
An Address to Catholic Employers
}

\section{Pius XII}

Volume 4, numéro 9, mai 1949

URI : https://id.erudit.org/iderudit/1023969ar

DOI : https://doi.org/10.7202/1023969ar

Aller au sommaire du numéro

Éditeur(s)

Département des relations industrielles de l’Université Laval

ISSN

0034-379X (imprimé)

1703-8138 (numérique)

Découvrir la revue

Citer cet article

Pius XII (1949). An Address to Catholic Employers. Relations industrielles / Industrial Relations, 4(9), 81-83. https://doi.org/10.7202/1023969ar
Résumé de l'article

In view of the great and general interest aruused by a French-language discourse of His Holiness Pop e Pius XII to delegates attending the Rome Congress of the International Union of Catholic Employers Associations, on May 7th, 1949, the comple text is presented herewith.
Tous droits réservés @ C Département des relations industrielles de l’Université Laval, 1949
Ce document est protégé par la loi sur le droit d'auteur. L’utilisation des services d'Érudit (y compris la reproduction) est assujettie à sa politique d'utilisation que vous pouvez consulter en ligne.

https://apropos.erudit.org/fr/usagers/politique-dutilisation/ 


\section{Bulletin des relations industrielles}

Volume 4, number 9

Published by the

\author{
Department of Industrial Relations, \\ Faculty of Social Sciences, \\ Laval University. \\ Georges-Henri Lévesque, o.p., Dean \\ Gérard Tremblay, Director \\ GÉrard Dion, Assistant-Director \\ Jean Gagné, Secretary \\ Charles Bélanger, Administrator
}

The Bulletin is published monthly, September to June inclusively (ten issues a year). Annual subscription: Canada: \$2.00; Foreign: \$2.50. Single copies: twenty-five cents.

Publication indexed in the

"Canadian Index".

All correspondance must be addressed to the Literary Editor

Gérard Dion

2, University Street, Quebec.

Bulletin des relations industrielles

Volume 4 , number 9

May 1949

\section{Contents}

An address to Catholic employers

His Holiness PIUs XII

The cancellation of a labour contract

Georges-Michel Grroux

Time off for employees to vote in an election.

Labour relations statistics

Thesis presented for the Master degree in industrial relations.

Church and Capitalism

Count della Torre

\section{Contributors}

Archambault, Jacques, B.A., M.Soc.Sc. Secretary, Central Council of the $\mathrm{Na}$ tional Catholic Syndicates of Joliette.

Giroux, Georges-Michel, N.P., LL.D., Technical Adviser, Minimum Wage Commission and Professor in the Faculties of Law and Social Sciences of Laval University.

Authorized as second class mail Post-office Department,

Ottawa, Canada.

\section{AN ADDRES TO CATHOLIC EMPLOYERS}

In view of the great and general interest aroused by a French-language discourse of His Holiness Pope Pius XII to delegates attending the Rome Congress of the International Union of Catholic Employers Associations, on May 7th, 1949, the complete text is presented herewith. ${ }^{1}$

\section{LABOR AND MANAGEMENT NEED COMMON FORMULA}

It is with equal solicitude and the same interest that We see coming to Us, each in turn, the workers and the representatives of industrial organizations, and both, one and the other, express to Us - with a confidence that deeply touches Us - their respective worries and problems.

Thus while welcoming you with Our whole heart, We most willingly take, dear sons, the opportunity that you afford to Us of expressing Our paternal pleasure and also to praise your zeal in spreading the Christian social doctrine in the economic world.

We allude to the worries and problems of those engaged in industrial production. Both false and evil in its consequences and, unhappily, only too widespread, is the prejudice which sees in those problems irreconcilable opposition between the various interests. That opposition, however, is merely apparent. In the economic sphere there is a community of activities and interests shared by leaders of industry and the workers. To disregard this mutual bond, or to endeavor to break it, can only be but the pretension of a blind and unreasonable despotism.

Employers and workers are not unreconcilable enemies. They are collaborators in a common effort, they eat, so to speak, at the same table since they live, eventually, from the gross or net profits of the national economy. Each has his income, and in this respect their mutual relations are not subordinated, one to the service of the other.

To earn one's living is an attribute of the personal dignity of anyone, who, in one form or another, makes his contribution to the service of the national economy. In the balance-sheet wages may figure as employers' expenses, but from the point of view of national economy, they are the expenditure of natural assets used for national production and, in consequence, must be in continual supply.

(1) The Catholic News, N.Y., Saturday, May 21, 1949. 
It follows that both parties have an interest in seeing that the cost of national production be in proportion to the returns. Since, however, the interest is mutual, why can it not find mutual expression in a common formula? Why should it not be lawful to give workers a fair share of responsibility in the establishment and development of national economy - and that nowadays more than ever when the scarcity of capital and difficulties of international exchanges paralyze the free flow of expenditure on national production ? Recent attempts at socialization have only made this sad reality even more clear. It is a fact; and neither has bad will of one side created it, nor can good will on the other side eliminate it.

While, then, there is still time, why not deal with the subject, in full appreciation of common responsibility, in such a way as to safeguard one side from undeserved diffidence, and the other from illusions that would not be long in becoming a social danger?

For this community of interest and responsibilities, in the sphere of national economy, Our evermemorable predecessor, Pope Pius XI, had already suggested a suitable and concrete formula, when in his encyclical «Quadragesimo Anno» he recommended professional organization in the various branches of production.

In fact, nothing seemed to him to be more fitted to overcome economic liberalism than the establishment of a statute of public law, for social economy, based precisely on the mutual responsibility of all those sharing the work of production. This passage of the encyclical aroused a series of objections. Some saw in it a concession to modern political opinions, while others regarded it as a return to the middle ages.

It would have been incomparably wiser to put aside old and inconsistent prejudices and come together, wholeheartedly and with good will, for the realization of such a project with its many practical applications.

Unfortunately, this part of the encyclical seems now to present us with yet another example of the ripe opportunity being missed, because it was not grasped at the right time. Subsequently, there have been attempts to elaborate other forms of juridical and public organization of the social economy, and at the present time preference is given to state and national ownership of industry.
There is no doubt that the Church, too, within certain just limits, approves nationalization and holds that one may legitimately reserve to public authority certain kinds of assets, namely those which are of such power and importance that they cannot be left in the hands of private individuals without endangering the common good. (From « Quadragesimo Anno »)

To make nationalization, however, the normal rule for public organization of economy would be to reverse the order of things. The object of public law is, in fact, to serve private rights, and not to absorb them. Economics are not, by their nature, a state institution, any more than any other branch of human activity. On the contrary, they are the living product of the free enterprise of individuals and of groups of individuals freely constituted.

Neither would it be correct to say that all private enterprise is, by nature, a society in which the relations between the collaborators be determined by the rules of distributive justice in such a way that all, without distinction - be they owners or not of the means of production - would have a right to share in the property, or at least in the profits of the enterprise.

\section{COOPERATION IS VITAL FOR A SOUND ECONOMY.}

Such a concept starts with the assumption that all enterprise, by its nature, comes within the sphere of public right. This assumption is false, whether the enterprise be constituted in the form of a foundation or an association of all the workers as co-proprietors, or it be the private property of an individual who signs a work-contract with his workers: it is amenable to the private juridical order of economic life.

All that We have just said refers to the juridical nature of enterprise as such, but the term « enterprise 》 can admit another entire category of other personal relations between collaborators, which must not be forgotten, and also the relations of mutual responsibility.

The proprietor of the means of production whether he be an individual, or an association, or a foundation of workers - must always remain the master in economic decisions, within the limits of public economic law. It is obvious that the share of the proprietor will be larger than that of 
his collaborators; but it follows that the material well-being of all the members of the nation which is the aim of social economy - obliges him more than the others to contribute to the increase of national assets by savings.

Just as one must not forget that is of supreme benefit to a sound social economy that this increase in assets should come from as many sources as possible, it is also greatly to be desired that the workers, too, should be able, as a result of their savings, to share in the building up of national assets.

Many men of industry, non-Catholics and Catholics such as you, have at various times expressly declared that the social doctrine of the Church - and that doctrine alone - is capable of providing the essential elements for a solution of the social question.
Undoubtedly, the putting into practice of this doctrine cannot be done in a day. Its realization requires of all wisdom, perspicacity and foresight, together with a large amount of common sense and good will. It requires of them, above all, a radical resistance to the temptation of each working for his own advantage at the expense of the others - regardless of the nature and form of their participation - or at the expense of the common good. It requires that altruism which only true Christian virtue, strengthened by the help and grace of God, can inspire.

To bring this help and grace on your association and its internal growth and external diffusion - particularly in those countries which even though Catholic need however to give wider consideration to the social teaching of the Church We give, with all the effusion of Our heart, to yourselves and your association, and under the powerful patronage of the Mother of Divine love, Our Apostolic Blessing.

\title{
THE CANCELLATION OF A LABOUR CONTRACT
}

\author{
Georges-Michel Giroux
}

The repeal of the Masters and Servants Act (R.S.Q., 1941, chapter 328) enacted by the Statute 13, George VI, Chapter 69, has modified the rules on the concellation of a labour contract. Many facts may extinguish the obligations resuiting from this contract, such as: mutual agreement, death of the employee (Civil Code, Art. 1668). The unilateral will of one of the parties may also terminate it; there is then cancellation of the labour contract.

To consider the concellation of the contract, it is necessary to analyze the rules on its duration and those on the term of notice; it is also necessary to examine the character of the provisions on the term of notice and the effect of the labour regulations on this subject.

\section{I - Duration of the curtract}

Anyone may, when it so pleases him, terminate a labour contract that binds him to another, it is quite obvious; an employer cannot be obliged to hire an employee and the latter, to work for an employer; memo ad actum cogi potest. The Canadian Labour Relations Board, under the rules of the Industrial Relations and Disputes Investigation Act (Canada, 11-12, George VI, chapter 54 ), may order an employer to take back in his employ, employees dismissed unjustly, (art. 40, 2); but the employer, if he does not conform to the Order only incurs penalties (art. 40, 3). An employee, even on the order of the Canadian Labour Relations Board, cannot work for an employer against the latter's will.

However, the legislator has determined the time in which the labour contract may be legally concelled by the will of one party and has ensured the injured party of an indemnity when the other party has improperly cancelled it. The law, and this is private law and not public law, wishes to ensure the respect of what has been agreed upon; it guarantees the maintenance of the engagement for the term, determined or determinable, fixed by the parties. The study of the cancellation of the labour contract leads to the examination of the legal rules on the duration.

The parties may decide on the duration of this contract:

a) for a definite term (C. C. art. 1667); 